Research Article

\section{Attitude of rabies among dog bite victims in Srinagar, Kashmir}

\author{
Namera Thahaby ${ }^{1 *}$, Afzal Hoque Akand ${ }^{2}$, Shabeer Ahmed Hamdani², \\ Abdul Hai Bhat ${ }^{3}$, Sanobar Rasool ${ }^{4}$, Niha Ayman ${ }^{5}$ and Shiekh Shubeena ${ }^{6}$ \\ ${ }^{1}$ PhD Scholar, Division of Veterinary and Animal Husbandry Extension, FVSc \& AH, SKUAST-Kashmir, \\ Srinagar, J \& K, India
}

${ }^{2}$ Assistant Professor, Division of Veterinary and Animal Husbandry Extension, FVSc \& AH, SKUASTKashmir, Srinagar, J \& K, India

${ }^{3}$ Professor \& Head, Division of Veterinary and Animal Husbandry Extension, FVSc \& AH, SKUASTKashmir, Srinagar, J \& K, India

${ }^{4} \mathrm{PhD}$ Scholar Division of Veterinary and Animal Husbandry Shuhama, Srinagar, India

${ }^{5}$ Mvsc Division of Veterinary and Animal Husbandry Shuhama, Srinagar, India

${ }^{6} \mathrm{PhD}$ Scholar, Division of Veterinary and Animal Husbandry Extension Shuhama Srinagar, India
Received: 04 November, 2020

Accepted: 22 February, 2021

Published: 23 February, 2021

*Corresponding author: Dr. Namera Thahaby, PhD Scholar, Division of Veterinary and Animal Husbandry Extension, FVSc \& AH, SKUAST-Kashmir, Srinagar, J \& K, India, Tel: 7006570307;

Email:nimrazahbi@gmail.com

Keywords: Attitude; Rabies; Dog bites; Victimized; Srinagar

https://www.peertechz.com

Check for updates

\begin{abstract}
Background: The Indian Association for the prevention and control of rabies estimates that 80, 00, 000 individuals receive the treatment for dog bites each year. The matter with dog rabies in India is that dogs are asymptomatic in each human establishment. The dog population is calculable to be about 25 million; most of them are ownerless and non-vaccinated against rabies. The purpose of the study was to see the attitude of dog bite victims towards rabies.
\end{abstract}

Methods: The present study was carried in Srinagar district. Regarding the attitude of people, an interview schedule was formulated.

Results: With regards to all dogs are dangerous the majority, $82.50 \%$ agreed. When asked about stray dogs are vicious the majority, $82.50 \%$ agreed. Only $17.50 \%$ agreed that dogs bark when they are frightened. About attack for no reason, the majority $92.50 \%$ agreed. About roaming of stray dogs unless they cause problems in human society, just $17.50 \%$ agreed. The majority $92.50 \%$ didn't agreed about the person provoking the dog for an attack. Whilst $100 \%$ highlighted that stray dogs are a problem in Kashmir. When asked about the population of stray dogs $100 \%$ agreed that there are too many dogs in Srinagar.

Conclusion: The attitude of the victimized people was positive. The majority, of respondents, alleged that stray dogs are a community vigour hitch within Srinagar. The outlook of respondents about not allotting stray dogs to meander copiously, appearing for medicinal consideration if bitten by a dog is shimmering proletariats concern in the control of rabies.

\section{Introduction}

The Indian Association for the prevention and control of rabies estimates that $80,00,000$ individuals receive the treatment for dog bites each year [1]. The matter with dog rabies in India is that dogs are asymptomatic in each human establishment. The dog population is calculable to be about 25 million; most of them are ownerless and non-vaccinated against Rabies. The calculable animal bite load per annum was a pair of 2.8 million. Within the capital town of an urban center, the amount of cases regarding dog bites has enlarged from 23,852 in 1992 to 29,905 in 1998 [2]. In Mumbai, 82, 247 cases of dog bites were rumored in 2012 [3] and cases of dog bites are rumored from varied states of India. Just, a British lady was bitten by a puppy in the state of Goa and she died in a U.K. hospital as of Rabies [4]. Youngsters represent 30 to $50 \%$ 
of those receiving post-exposure vaccinations or dying from the disease. An individual is bitten each a pair of seconds and somebody dies from rabies each half-hour in India [5].

\section{Research methodology}

The present study was carried in Srinagar district of Jammu and Kashmir Union Territories (Erstwhile Jammu and Kashmir State), India. The purpose is to know the attitude of people towards rabies and thereby the selection of such people comes in front which was done using the below-mentioned sampling plan within the Srinagar district. As per Srinagar Municipal Corporation (SMC), the city is divided into two divisions, four zones and 34 administrative wards (Table 1). The four administrative zones are North, South, East, and West. To maximize the diversity of population response, all the four zones were considered for the present investigation. From each zone, 4 wards were selected randomly making a total of 16 wards. The wards that were selected were shown in the Table 1 with yellow colour. From each randomly selected ward, 10 household exposed to rabies/dog bite were selected as respondents for data collection (accidental sampling). Thus a total of 160 respondents were the sample size for investigating the attitude of rabies vis-a-vis dog bite exposure among the human population. Our assessment consisted of inquiries to grasp the study's objectives. Five domains were used to prove attitudes amid regards to rabies. Largely attitude level of every domain was seen. Finally, the chi-square test, fisher exact test was accustomed to inspecting the connection amongst variables and consequently, the files had analyzed the using of the SPSS 20.0 software.

\section{Result}

With regards to all dogs are dangerous the majority, $82.50 \%$ agreed. When asked about stray dogs are vicious the majority, $82.50 \%$ agreed. Only $17.50 \%$ agreed that dogs bark when they are frightened (Table 2). About attack for no reason, the majority $92.50 \%$ agreed. About roaming of stray dogs unless they cause problems in human society, just $17.50 \%$ agreed. The majority $92.50 \%$ didn't agreed about the person provoking the dog for an attack. Whilst 100\% highlighted that stray dogs are a problem in Kashmir. When asked about the population of stray dogs $100 \%$ agreed that there are too many dogs in Srinagar. About leashing during an outbreak, the majority $17.50 \%$ agreed. The majority $92.50 \%$ were not aware about the killing of dogs is considered as a religious taboo. It is evident from the (Table 3 ) for supporting the rabies program the majority, $92.50 \%$ agreed. About $17.50 \%$ agreed it is a threat to human health. When asked about it is transmitted from dogs, therefore it should be controlled, $17.50 \%$ agreed. Also $17.50 \%$ agreed that rabies can be effectively prevented by vaccination. The majority, $92.50 \%$ were willing to euthanize stray dogs for rabies prevention. When asked about educating people can prevent it all $100 \%$ agreed. It is obvious to seek medical attention with rabies exposure; the majority $82.50 \%$ remained neutral. When asked about educating children as it can act as a herd to awareness, the majority $82.50 \%$ remained neutral (Table 4). With regards to insufficiency of legislation by the government regarding rabies, most $82.50 \%$ remained neutral. Regarding awareness of population in Srinagar about rabies, the majority $100 \%$ agreed. Limited budget is given to his hospital for dog bite cases; the majority $82.50 \%$ remained neutral. It is important to get assistance from the animal department if there is a rabid dog; the majority $82.50 \%$ remained neutral. If there is a rabies control program in Srinagar, the majority $100 \%$ agreed of supporting it. Vaccines are not available throughout the year at the SMHS hospital; the majority $82.50 \%$ remained neutral. When asked about there is lone anti-rabies clinic in Kashmir at SMHS hospital, the majority $92.50 \%$ agreed. I would take vaccine if bitten by a dog, the majority $100 \%$ agreed. The majority $82.50 \%$ remained neutral about wound cleaning before reaching to the hospital. About the anti-rabies vaccine and its safety for prevention, the majority $100 \%$ agreed. The majority $82.50 \%$ remained neutral about suggesting rabies vaccine to others (Table 5 ).

\section{Discussion}

Rabies is out looked as awful of the diseases that attack humans. This discriminating alarm, outdoing any exact civic wellbeing hazard, is owing to abundant issues whilst were seen besides rabies initially put on its inkling as a misery. The current issues also symbolize that the attitudes of the respondent were positive. The majority, of respondents, alleged that stray dogs are a community vigour hitch within Srinagar. The outlook of respondents about not allotting stray dogs to meander

Table 1: Different zones and the wards of Srinagar district as per Srinagar Municipal Corporation.

\begin{tabular}{|c|c|c|c|c|}
\hline Wards & $\begin{array}{l}\text { North zone } \\
\text { (9 wards) }\end{array}$ & $\begin{array}{l}\text { South zone } \\
\text { ( } 9 \text { wards) }\end{array}$ & $\begin{array}{l}\text { East zone } \\
\text { (8 wards) }\end{array}$ & $\begin{array}{l}\text { West zone } \\
\text { (8wards) }\end{array}$ \\
\hline 1 & Tarbal, JamiaMasjid,Kawdara & Malroo, Lawaypora & Harwan, Nishat & SafaKadal, IddGah \\
\hline 2 & Zadibal,Madeen Sahib & BeminaKhumaniChowk & Dalgate, Lalchowk & Palpora \\
\hline 3 & Lal Bazaar, Umer Colony & AllochiBagh, MagermalBagh & Dud Dal, Locut dal & Nawab Bazaar, Ali Kadal \\
\hline 4 & Hazratbal,Tailbal & Rajbagh, JawaharNagar,WazirBagh & JogiLankar, Zindashah Sahib & Syed Ali Akbar, Islam Yarbal \\
\hline 5 & New Theed, Alusteng & Mahjoor Nagar, Natipora, Chanapora & Ganpatyar, Barbarshah & Shaheed Gung, Karan Nagar \\
\hline 6 & Zakoora & BaghatBarzallua, Rawalpora & BanaMohalla,ChinkralMohalla, S.R.Gung & Qamarwari, Chattabal \\
\hline 7 & Ahmad Nagar & Humhama & Akil Mir Khanyar, Khaja Bazar & Bemina East, BeminaWest \\
\hline 8 & Soura, Buchpora & PanthaChowk, Khanmoh & Hasna Abad, Makhdoom Sahib & Parimpora, Zainakote \\
\hline 9 & Nowshahra, Zoonimar & $\begin{array}{l}\text { S.D.colonyBatamaloo } \\
\text { Nundrash colony }\end{array}$ & & \\
\hline
\end{tabular}


Table 2: Distribution of respondents according to attitude towards stray dogs.

\begin{tabular}{|c|c|c|c|c|c|c|}
\hline \multirow{3}{*}{\multicolumn{2}{|c|}{ Attitude towards stray dogs }} & \multicolumn{4}{|c|}{ Zones } & \multirow{3}{*}{$\begin{array}{c}\text { Pooled } \\
\text { N }\end{array}$} \\
\hline & & North & West & South & East & \\
\hline & & \multicolumn{4}{|c|}{$\mathbf{n}$} & \\
\hline Statement & Response & 10 & 10 & 10 & 10 & 40 \\
\hline \multirow{3}{*}{ All dogs are dangerous } & Agree & $8(80)$ & 10(100) & $6(60)$ & $9(90)$ & $33(82.50)$ \\
\hline & Not agree & $0(0.00)$ & $0(0.00)$ & $0(0.00)$ & $0(0.00)$ & $0(0.00)$ \\
\hline & Not decided & $2(20)$ & $0(0.00)$ & $4(40)$ & $1(10)$ & $7(17.50)$ \\
\hline \multirow{3}{*}{ Stray dogs by nature are more vicious } & Agree & $8(80)$ & $10(100)$ & $6(60)$ & $9(90)$ & $33(82.50)$ \\
\hline & Not agree & $0(0.00)$ & $0(0.00)$ & $0(0.00)$ & $0(0.00)$ & $0(0.00)$ \\
\hline & Not decided & $2(20)$ & $0(0.00)$ & $4(40)$ & $1(10)$ & $7(17.50)$ \\
\hline \multirow{3}{*}{ One of the reason dog barks is because they are frightened } & Agree & $2(20)$ & $0(0.00)$ & $4(40)$ & $1(10)$ & $7(17.50)$ \\
\hline & Not agree & $8(80)$ & $10(100)$ & $6(60)$ & $9(90)$ & $33(82.50)$ \\
\hline & Not decided & $0(0.00)$ & $0(0.00)$ & $0(0.00)$ & $0(0.00)$ & $0(0.00)$ \\
\hline \multirow{3}{*}{ Sometimes stray dog bark to annoy you } & Agree & $0(0.00)$ & $0(0.00)$ & $0(0.00)$ & $0(0.00)$ & $0(0.00)$ \\
\hline & Not agree & $2(20)$ & $0(0.00)$ & $4(40)$ & $1(10)$ & $7(17.50)$ \\
\hline & Not decided & $8(80)$ & $10(100)$ & $6(60)$ & $9(90)$ & $33(82.50)$ \\
\hline \multirow{3}{*}{ Most of the time, dog attacks people for no reason } & Agree & $9(90)$ & 10(100) & $8(80)$ & $10(100)$ & $37(92.50)$ \\
\hline & Not agree & $0(0.00)$ & $0(0.00)$ & $0(0.00)$ & $0(0.00)$ & $0(0.00)$ \\
\hline & Not decided & $1(10)$ & $0(0.00)$ & $2(20)$ & $0(0.00)$ & $3(7.50)$ \\
\hline \multirow{3}{*}{ Stray dogs should not be allowed to roam unless they cause problems in human society } & Agree & $2(20)$ & $0(0.00)$ & $4(40)$ & $1(10)$ & $7(17.50)$ \\
\hline & Not agree & $8(80)$ & $10(100)$ & $6(60)$ & $9(90)$ & $33(82.50)$ \\
\hline & Not decided & $0(0.00)$ & $0(0.00)$ & $0(0.00)$ & $0(0.00)$ & $0(0.00)$ \\
\hline \multirow{3}{*}{ If dog attacks someone, it is because that the person provoked it } & Agree & $0(0.00)$ & $0(0.00)$ & $0(0.00)$ & $0(0.00)$ & $0(0.00)$ \\
\hline & Not agree & $9(90)$ & $10(100)$ & $8(80)$ & $10(100)$ & $37(92.50)$ \\
\hline & Not decided & $1(10)$ & $0(0.00)$ & $2(20)$ & $0(0.00)$ & $3(7.50)$ \\
\hline \multirow{3}{*}{$\begin{array}{l}\text { Stray dogs is a problem in } \\
\text { Kashmir }\end{array}$} & Agree & 10(100) & 10(100) & $10(100)$ & $10(100)$ & $40(100)$ \\
\hline & Not agree & $0(0.00)$ & $0(0.00)$ & $0(0.00)$ & $0(0.00)$ & $0(0.00)$ \\
\hline & Not decided & $0(0.00)$ & $0(0.00)$ & $0(0.00)$ & $0(0.00)$ & $0(0.00)$ \\
\hline \multirow{3}{*}{$\begin{array}{l}\text { There are too many stray dogs } \\
\text { in Srinagar }\end{array}$} & Agree & 10(100) & $10(100)$ & $10(100)$ & $10(100)$ & $40(100)$ \\
\hline & Not agree & $0(0.00)$ & $0(0.00)$ & $0(0.00)$ & $0(0.00)$ & $0(0.00)$ \\
\hline & Not decided & $0(0.00)$ & $0(0.00)$ & $0(0.00)$ & $0(0.00)$ & $0(0.00)$ \\
\hline \multirow{3}{*}{ Leashing of stray dogs during the outbreak can prevent rabies cases in humans } & Agree & 2(20) & $0(0.00)$ & $4(40)$ & $1(10)$ & $7(17.50)$ \\
\hline & Not agree & $0(0.00)$ & $0(0.00)$ & $0(0.00)$ & $0(0.00)$ & $0(0.00)$ \\
\hline & Not decided & $8(80)$ & $10(100)$ & $6(60)$ & $9(90)$ & $33(82.50)$ \\
\hline \multirow{3}{*}{ Killing of dogs is considered as a religious taboo } & Agree & $0(0.00)$ & $0(0.00)$ & $0(0.00)$ & $0(0.00)$ & $0(0.00)$ \\
\hline & Not agree & $9(90)$ & $10(100)$ & $8(80)$ & $10(100)$ & $37(92.50)$ \\
\hline & Not decided & $1(10)$ & $0(0.00)$ & $2(20)$ & $0(0.00)$ & $3(7.50)$ \\
\hline
\end{tabular}

Figures in parenthesis indicate percentage, $n$ : Indicates sample size; " $N$ ": Total sample size.

Table 3: Distribution of respondents according to attitude towards rabies disease.

\begin{tabular}{|c|c|c|c|c|c|c|}
\hline \multirow{3}{*}{\multicolumn{2}{|c|}{ Attitude towards rabies disease }} & \multicolumn{4}{|c|}{ Zones } & \multirow{3}{*}{$\begin{array}{c}\text { Pooled } \\
\mathbf{N}\end{array}$} \\
\hline & & North & West & South & East & \\
\hline & & \multicolumn{4}{|c|}{ n } & \\
\hline Question & Response & 10 & 10 & 10 & 10 & 40 \\
\hline \multirow{3}{*}{ Rabies control program should be supported } & Agree & $9(90)$ & $10(100)$ & $8(80)$ & $10(100)$ & $37(92.50)$ \\
\hline & Not agree & $0(0.00)$ & $0(0.00)$ & $0(0.00)$ & $0(0.00)$ & $0(0.00)$ \\
\hline & Not decided & $1(10)$ & $0(0.00)$ & $2(20)$ & $0(0.00)$ & $3(7.50)$ \\
\hline \multirow{3}{*}{ Rabies is a threat for human health, therefore it should be controlled } & Agree & $2(20)$ & $0(0.00)$ & $4(40)$ & $1(10)$ & $7(17.50)$ \\
\hline & Not agree & $0(0.00)$ & $0(0.00)$ & $0(0.00)$ & $0(0.00)$ & $0(0.00)$ \\
\hline & Not decided & $8(80)$ & 10(100) & $6(60)$ & $9(90)$ & $33(82.50)$ \\
\hline \multirow{3}{*}{ Rabies is transmitted by dogs, therefore it should be controlled } & Agree & $2(20)$ & $0(0.00)$ & $4(40)$ & $1(10)$ & $7(17.50)$ \\
\hline & Not agree & $0(0.00)$ & $0(0.00)$ & $0(0.00)$ & $0(0.00)$ & $0(0.00)$ \\
\hline & Not decided & $8(80)$ & 10(100) & $6(60)$ & $9(90)$ & $33(82.50)$ \\
\hline \multirow{3}{*}{ Rabies can be effectively prevented by vaccinating dogs } & Agree & $2(20)$ & $0(0.00)$ & $4(40)$ & $1(10)$ & $7(17.50)$ \\
\hline & Not agree & $0(0.00)$ & $0(0.00)$ & $0(0.00)$ & $0(0.00)$ & $0(0.00)$ \\
\hline & Not decided & $8(80)$ & 10(100) & $6(60)$ & $9(90)$ & $33(82.50)$ \\
\hline \multirow{3}{*}{ Rabies can be prevented by euthanizing stray dogs } & Agree & $9(90)$ & 10(100) & $8(80)$ & 10(100) & $37(92.50)$ \\
\hline & Not agree & $0(0.00)$ & $0(0.00)$ & $0(0.00)$ & $0(0.00)$ & $0(0.00)$ \\
\hline & Not decided & $1(10)$ & $0(0.00)$ & $2(20)$ & $0(0.00)$ & $3(7.50)$ \\
\hline \multirow{3}{*}{ Rabies can be prevented by educating people } & Agree & 10(100) & $10(100)$ & $10(100)$ & $10(100)$ & $40(100)$ \\
\hline & Not agree & $0(0.00)$ & $0(0.00)$ & $0(0.00)$ & $0(0.00)$ & $0(0.00)$ \\
\hline & Not decided & $0(0.00)$ & $0(0.00)$ & $0(0.00)$ & $0(0.00)$ & $0(0.00)$ \\
\hline \multirow{3}{*}{ Informed individuals can avoid exposure to rabies and seek appropriate medical attention } & Agree & $2(20)$ & $0(0.00)$ & $4(40)$ & $1(10)$ & $7(17.50)$ \\
\hline & Not agree & $0(0.00)$ & $0(0.00)$ & $0(0.00)$ & $0(0.00)$ & $0(0.00)$ \\
\hline & Not decided & $8(80)$ & 10(100) & $6(60)$ & $9(90)$ & $33(82.50)$ \\
\hline
\end{tabular}

Citation: Thahaby N, Akand AH, Hamdani SA, Bhat AH, Rasool S, et al. (2021) Attitude of rabies among dog bite victims in Srinagar, Kashmir. Glob J Infect Dis Clin Res 7(1): 016-020. DOl: https://doi.org/10.17352/2455-5363.000041 
Table 4: Distribution of respondents according to attitude towards awareness.

\begin{tabular}{|c|c|c|c|c|c|c|}
\hline \multirow{3}{*}{\multicolumn{2}{|c|}{ Attitude towards awareness }} & \multicolumn{4}{|c|}{ Zones } & \multirow{3}{*}{ pooled } \\
\hline & & North & West & South & East & \\
\hline & & \multicolumn{4}{|c|}{$\mathbf{n}$} & \\
\hline Question & Response & 80 & 80 & 80 & 80 & 320 \\
\hline \multirow{3}{*}{$\begin{array}{l}\text { Health education to children is essential as it can act as a herd community to increased } \\
\text { awareness }\end{array}$} & Agree & $2(20)$ & $0(0.00)$ & $4(40)$ & $1(10)$ & $7(17.50)$ \\
\hline & Not agree & $0(0.00)$ & $0(0.00)$ & $0(0.00)$ & $0(0.00)$ & $0(0.00)$ \\
\hline & Not decided & $8(80)$ & $10(100)$ & $6(60)$ & $9(90)$ & $33(82.50)$ \\
\hline \multirow{3}{*}{ There is insufficiency of legislation policy by the government regarding rabies } & Agree & $2(20)$ & $0(0.00)$ & $4(40)$ & $1(10)$ & $7(17.50)$ \\
\hline & Not agree & $0(0.00)$ & $0(0.00)$ & $0(0.00)$ & $0(0.00)$ & $0(0.00)$ \\
\hline & Not decide & $8(80)$ & $10(100)$ & $6(60)$ & $9(90)$ & $33(82.50)$ \\
\hline \multirow{3}{*}{ There is lack of awareness in Srinagar population regarding rabies } & Agree & $10(100)$ & $10(100)$ & $10(100)$ & $10(100)$ & $40(100)$ \\
\hline & Not agree & $0(0.00)$ & $0(0.00)$ & $0(0.00)$ & $0(0.00)$ & $0(0.00)$ \\
\hline & Not decide & $0(0.00)$ & $0(0.00)$ & $0(0.00)$ & $0(0.00)$ & $0(0.00)$ \\
\hline \multirow{3}{*}{ Limited budget is provided to SMHS hospital for dog bite cases } & Agree & $2(20)$ & $0(0.00)$ & $4(40)$ & $1(10)$ & $7(17.50)$ \\
\hline & Not agree & $0(0.00)$ & $0(0.00)$ & $0(0.00)$ & $0(0.00)$ & $0(0.00)$ \\
\hline & Not decided & $8(80)$ & $10(100)$ & $6(60)$ & $9(90)$ & $33(82.50)$ \\
\hline \multirow{3}{*}{$\begin{array}{l}\text { It is important to get assistance from animal department if I see a rabid dog inside my } \\
\text { house/residence }\end{array}$} & Agree & $2(20)$ & $0(0.00)$ & $4(40)$ & $1(10)$ & $7(17.50)$ \\
\hline & Not agree & $0(0.00)$ & $0(0.00)$ & $0(0.00)$ & $0(0.00)$ & $0(0.00)$ \\
\hline & Not decided & $8(80)$ & $10(100)$ & $6(60)$ & $9(90)$ & $33(82.50)$ \\
\hline \multirow{3}{*}{ You will support rabies control in Srinagar } & Agree & $10(100)$ & $10(100)$ & $10(100)$ & $10(100)$ & $40(100)$ \\
\hline & Not agree & $0(0.00)$ & $0(0.00)$ & $0(0.00)$ & $0(0.00)$ & $0(0.00)$ \\
\hline & Not decided & $0(0.00)$ & $0(0.00)$ & $0(0.00)$ & $0(0.00)$ & $0(0.00)$ \\
\hline
\end{tabular}

Figures in parenthesis indicate percentage, $n$ : Indicates sample size; " $N$ ": Total sample size

Table 5: Distribution of respondents according to attitude towards rabies vaccine.

\begin{tabular}{|c|c|c|c|c|c|c|}
\hline \multirow{3}{*}{\multicolumn{2}{|c|}{ Attitude towards rabies vaccine }} & \multicolumn{4}{|c|}{ Zones } & \multirow{3}{*}{$\begin{array}{c}\text { Pooled } \\
\mathbf{N}\end{array}$} \\
\hline & & North & West & South & East & \\
\hline & & \multicolumn{4}{|c|}{$\mathbf{n}$} & \\
\hline Question & Response & 10 & 10 & 10 & 10 & 40 \\
\hline \multirow{3}{*}{ Vaccines are not available throughout the year at SMHS ospital } & Agree & $2(20)$ & $0(0.00)$ & $4(40)$ & $1(10)$ & $7(17.50)$ \\
\hline & Not agree & $0(0.00)$ & $0(0.00)$ & $0(0.00)$ & $0(0.00)$ & $0(0.00)$ \\
\hline & Not decided & $8(80)$ & $10(100)$ & $6(60)$ & $9(90)$ & $33(82.50)$ \\
\hline \multirow{3}{*}{ There is lone anti rabies clinic in Kashmir in Kashmir at SMHS hospital } & Agree & $9(90)$ & $10(100)$ & $8(80)$ & $10(100)$ & $37(92.50)$ \\
\hline & Not agree & $0(0.00)$ & $0(0.00)$ & $0(0.00)$ & $0(0.00)$ & $0(0.00)$ \\
\hline & Not decided & $1(10)$ & $0(0.00)$ & $2(20)$ & $0(0.00)$ & $3(7.50)$ \\
\hline \multirow{3}{*}{ I would take vaccine, if I encounter a dog bite } & Agree & $10(100)$ & $10(100)$ & $10(100)$ & $10(100)$ & $40(100)$ \\
\hline & Not agree & $0(0.00)$ & $0(0.00)$ & $0(0.00)$ & $0(0.00)$ & $0(0.00)$ \\
\hline & Not decided & $0(0.00)$ & $0(0.00)$ & $0(0.00)$ & $0(0.00)$ & $0(0.00)$ \\
\hline \multirow{3}{*}{ If I get bitten by a dog, I would clean the wound and consult doctors as soon as possible } & Agree & 2(20) & $0(0.00)$ & $4(40)$ & $1(10)$ & $7(17.50)$ \\
\hline & Not agree & $\begin{array}{c}0 \\
(0.00)\end{array}$ & $\begin{array}{c}0 \\
(0.00)\end{array}$ & $\begin{array}{c}0 \\
(0.00)\end{array}$ & $\begin{array}{c}0 \\
(0.00)\end{array}$ & $\begin{array}{c}0 \\
(0.00)\end{array}$ \\
\hline & Not decided & $8(80)$ & $10(100)$ & $6(60)$ & $9(90)$ & $33(82.50)$ \\
\hline \multirow{3}{*}{ Anti rabies vaccine is safe for preventing rabies } & Agree & $10(100)$ & $10(100)$ & $10(100)$ & $10(100)$ & $40(100)$ \\
\hline & Not agree & $0(0.00)$ & $0(0.00)$ & $0(0.00)$ & $0(0.00)$ & $0(0.00)$ \\
\hline & Not decided & $0(0.00)$ & $0(0.00)$ & $0(0.00)$ & $0(0.00)$ & $0(0.00)$ \\
\hline \multirow{3}{*}{ I would recommend anti rabies vaccine to others } & Agree & $2(20)$ & $0(0.00)$ & $4(40)$ & $1(10)$ & $7(17.50)$ \\
\hline & Not agree & $0(0.00)$ & $0(0.00)$ & $0(0.00)$ & $0(0.00)$ & $0(0.00)$ \\
\hline & Not decided & $8(80)$ & $10(100)$ & $6(60)$ & $9(90)$ & $33(82.50)$ \\
\hline
\end{tabular}

Figures in parenthesis indicate percentage, $n$ : Indicates sample size; " $N$ ": Total sample size

copiously, appearing for medicinal consideration if bitten by a dog is shimmering proletariats concern in the control of rabies. The mainstream assumed that the health educators aim ought to squeeze the outline of human deaths from the disease. Consequently, it is very vital to craft perception in the community about this. The bulk, required to have the rabies control program in Srinagar. While their eagerness is not a pledge on obliging with the administration in rabies control. The motive is there had been no national rabies control plan in Srinagar. The pessimistic approach on waste supervision might be due to extra refuse plus dogs that are seen on the avenues.

\section{Conclusion}

The attitude of the victimized people was positive. The majority, of respondents, alleged that stray dogs are a community vigour hitch within Srinagar. The outlook of respondents about not allotting stray dogs to meander copiously, appearing for medicinal consideration if bitten by a dog is shimmering proletariats concern in the control of rabies.

\section{Ethics statement}

The study was approved by the faculty of veterinary and 
animal husbandry Srinagar, Kashmir, India. Our assessment consisted of inquiries to grasp the study's objectives. Five domains have been used to verify attitudes with regards to rabies protecting the first useful resource and scientific interest and motion closer to suspect rabid animals. Scores were given under the completeness and accuracy of respondent's answers.

\section{References}

1. Dubal ZB, Barbuddhe SB, Singh NP (2014) Important Zoonotic diseases: prevention and control. Indian Council of Agricultural Research 39: 9. Link: https://bit.ly/3qLDGLU
2. Bansal RK (2004) Making India rabies free country. J Assoc Physicians India 52: 79. Link: https://bit.ly/3aGINbB

3. Chatterjee S, Riaz H (2013) Rabies: beware of the dog. Br Med J 347: f5912 Link: https://bit.ly/3sfFcpF

4. Scott K (2005) Rabies victim dies. Guardian. Link: https://bit.ly/3uo7Vug

5. Menezes R (2008) Rabies in India. J Can Med Assoc 178: 564-566. Link: https://bit.ly/3brEoHE
Discover a bigger Impact and Visibility of your article publication with

Peertechz Publications

\section{Highlights}

* Signatory publisher of ORCID

* Signatory Publisher of DORA (San Francisco Declaration on Research Assessment)

- Articles archived in worlds' renowned service providers such as Portico, CNKI, AGRIS, TDNet, Base (Bielefeld University Library), CrossRef, Scilit, J-Gate etc.

* Journals indexed in ICMJE, SHERPA/ROMEO, Google Scholar etc.

* OAI-PMH (Open Archives Initiative Protocol for Metadata Harvesting)

* Dedicated Editorial Board for every journa

* Accurate and rapid peer-review process

* Increased citations of published articles through promotions

* Reduced timeline for article publication

Submit your articles and experience a new surge in publication services

(https://www.peertechz.com/submission).

Peertechz journals wishes everlasting success in your every endeavours.

Copyright: @ 2021 Thahaby N, et al. This is an open-access article distributed under the terms of the Creative Commons Attribution License, which permits unrestricted use, distribution, and reproduction in any medium, provided the original author and source are credited. 